\title{
Цай Л.А. \\ Использование электрокоагуляции для остановки кровотечений из задних отделов полости носа
}

МБУЗ ГБ № 1 им. Н.А. Семашко

(Россия, Ростов-на-Дону)

doi: $10.18411 / \mathrm{j}-08-2021-08$

\section{Аннотация}

Проведен ретроспективный анализ результатов лечения 167 больных с кровотечениями из задних отделов полости носа. Возраст больных был от 32 до 73 лет. В большинстве случаев источник кровотечения при первичном осмотре обнаружить не удалось. Оптимальным терапевтическим подходом в этих случаях была идентификация кровоточащего сосуда и его коагуляция при эндоскопическом исследовании полости носа. Если при рецидивирующем НК поиск источника кровотечения был затруднен узостью полости носа из-за наличия девиации перегородки, выполняли корригирующую операцию с эндоскопической ревизией задних отделов полости носа и электрокоагуляцией кровоточивой зоны.

Ключевые слова: носовое кровотечение, эндоскопическая электрокоагуляция.

\section{Abstract}

The retrospective analysis of hospital charts of 167 patients with posterior epistaxis aged from 32 to 73 was carried out. The bleeding point was unknown in most cases of first examination. Identifying the bleeding points as much as possible and performing electrocoagulation at these sites was the preferred procedures. We propose the treatment procedure for refractory epistaxis. When it is difficult to identify a bleeding point in a patient with refractory epistaxis due to a deviated nasal septum, a bleeding point should be identified after septoplasty.

Keywords: epistaxis, endoscopic electrocoagulation.

Носовое кровотечение (НК) - одна из самых частых причин экстренных обращений к оториноларингологу. Хотя у подавляющего большинства больных с НК кровотечение может быть остановлено в амбулаторных условиях, существует группа больных, которые требуют госпитализации и даже в условиях стационара представляет определенные трудности для лечения. Это больные с рецидивирующими НК, возникающими на фоне плохо контролируемой артериальной гипертензии, длительного приема антикоагулянтов или коморбидных нарушений гемостаза, и, особенно, больные с идиопатическими НК, у которых причину установить не удается $[1,2,3]$. До недавнего времени основным методом остановки рецидивирующих НК была тампонада полости носа $[4,5]$. С развитием техники эндоназальной эндоскопической хирургии все шире стали использовать электрокоагуляцию кровоточащих сосудов в полости носа, в том числе, при их локализации в задних отделах полости носа $[6,7]$.

Целью нашей работы было изучение возможности применения электрокоагуляции при кровотечениях из задних отделов полости носа.

Материал и методы исследования. Проведен ретроспективный анализ стационарных историй болезни пациентов, госпитализированных по поводу рецидивирующих НК. При анализе анамнестических данных выявляли указания на артериальную гипертензию, прием антикоагулянтов, нарушений в системе гемостаза, травмы, аллергический ринит, хронический риносинусит, перенесенные в недавнем прошлом хирургические вмешательства в полости носа. Из общего массива отобрано 167 больных с идиопатическими НК в возрасте от 32 до 73 лет. При передней риноскопии источник НК не был обнаружен, ввиду чего кровотечение было 
остановлено в приемном отделении передней тампонадой. Однако после извлечения тампонов через 20 - 28 часов оно возобновилось у 42 больных.

Для поиска источника НК больным было произведено эндоскопическое исследование полости носа. Исследование проводилось в положении больного сидя со слегка наклоненной вперед головой. При обильном кровотечении в задний отдел полости носа вводили марлевый тампон для предотвращения затекания крови в глотку. Осмотр полости носа с использованием электроотсоса подтвердил, что кровоточащий сосуд располагается в средних (у 14 больных) и задних отделах полости носа (22 больных). У 6 больных осмотреть кровоточащую половину полости носа не удалось ввиду наличия резко выраженного искривления перегородки носа, препятствующего введению жесткого эндоскопа.

В тех случаях, когда кровоточащий сосуд определялся в средних отделах полости носа (в области средней носовой раковины, дна полости носа, средний отдел нижней носовой раковины и перегородки носа) гемостаз осуществляли под местной аппликационной анестезией $10 \%$ раствором лидокаина с помощью аппарата «Фотек Е 80 М» в режиме «монокоагуляция». Если контакт с зоной кровоточивости был затруднен, использовали режим «спрей».

У больных с локализацией источника кровотечения в задних отделах полости носа (в основном, в зоне венозного сплетения Woodruff под задним концом нижней носовой раковины) эндоскопическое обследование проводилось в положении лежа с приподнятым головным концом стола, помимо электроотсоса использовали орошение полости носа раствором транексамовой кислоты, подогретым до $42^{\circ}$, что значительно уменьшало интенсивность кровотечения [8]. При соблюдении этих условий кровоточащий сосуд был обнаружен и коагулирован с применением электрохирургического коагулятора ERBE серии V10C STORZ у 18 из 22 больных с хорошими анатомическими условиями обзора.

В 6 случаях наличия выраженной девиации перегородки носа гемостаз был произведен в условиях операционной, под общим обезболиванием, с предварительным вмешательством на перегородке носа (произведена септопластика) для обеспечения доступа к кровоточивой зоне.

Обсуждение результатов. Для проведения ретроспективного анализа мы выбрали истории болезни пациентов с так называемыми идиопатическими НК, исключив случаи, когда причина кровотечения очевидна (травма, прием антикоагулянтов, опухоль полости носа и другие). В этих случаях главным в системе лечебных мероприятий оказывается местный гемостаз, поскольку патогенетическая терапия является неочевидной. Основным условием успешной остановки НК является обнаружение кровоточащего сосуда, поскольку у пациентов с неустановленным источником кровотечения риск его рецидивов возрастает приблизительно в 3 раза [9]. Последовательность применения мероприятий с целью остановки НК нам представляется следующим образом: при первичном осмотре больного необходимо определить область локализации кровоточащего сосуда в полости носа (передние или задние отделы). Кровотечение из передних отделов перегородки носа должно быть остановлено бестампонным способом, тампонада в этих случаях является методом выбора при неэффективности других приемов, либо при наличии гемодинамических нарушений у больного, требующих немедленной коррекции.

При кровотечении из задних отделов полости носа допустим первичный гемостаз с помощью тампонады носа, если источник НК не определяется. В последующем при возобновлении кровотечения после удаления тампонов должно быть произведено эндоскопическое исследование полости носа, идентификация источника НК и электрокоагуляция кровоточащего сосуда. При наличии выраженного искривления перегородки носа показана септопластика для обеспечения доступа к кровоточивой зоне. 
Как показало наше исследование, электрокоагуляция с эндоскопическим контролем является способом надежного гемостаза и профилактикой рецидивов носовых кровотечений.

1. Волков А.Г., Киселев В.В. Некоторые вопросы патофизиологии носовых кровотечений. Рос. ринология. 2001. № 4. С 26.

2. Бойко Н.В. Носовые кровотечения как осложнение антитромботической терапии. Российская ринология. 2011; 19(4): 29-32.

3. Саливончик Е.И., Яцкова О.В., Саливончик Д.П. Особенности носовых кровотечений у пациентов кардиологического профиля. Оториноларингология. Восточная Европа. 2014. № 3 (16). С. 73-82.

4. Бойко Н.В. Шатохин Ю.В. Алгоритм оказания неотложной помощи больным с носовым кровотечением. Рос. ринология. 2008; 16 (1): 41-44.

5. Горносталев Н.Я., Синитович Н.Ю., Шиленкова В.В., Анготоева И.Б. Сравнительное исследование эффективности и безопасности различных способов тампонады носа при носовых кровотечениях. Вестник оторинолар. 2013; 4:48-51.

6. Zhou AH; Chung SY; Sylvester MJ; et al. To Pack or Not to Pack: Inpatient Management of Epistaxis in the Elderly Am J Rhinol Allergy. 2018; 32(6):539-545.

7. Srinivasan V, Patel H, Iimura J. et al. Study of hemostasis procedures for posterior epistaxis. Auris Nasus Larynx. 2016; 43(3):298-303.

8. Бойко Н.В., Бачурина А.С., Жданов А.И. Профилактика послеоперационных кровотечений при аденотомии. Рос. ринология. 2015;23 (2): 26-30.

9. Iimura J., Hatano A., Ando Y., et al. Study of hemostasis procedures for posterior epistaxis. Auris Nasus Larynx. 2016; 43 (3): 298-303. 